Asian J. Med. Biol. Res. 2017, 3 (4), 476-487; doi: 10.3329/ajmbr.v3i4.35338

\author{
Asian Journal of \\ Medical and Biological Research \\ ISSN 2411-4472 (Print) 2412-5571 (Online) \\ www.ebupress.com/journal/ajmbr
}

\title{
Article \\ Effects of chemotherapeutics against experimentally injured stinging catfish Heteropneustes fossilis
}

\author{
Md. Sharif Neowajh ${ }^{1}$, M. Mamnur Rashid ${ }^{1}$, Abdulla-Al-Asif ${ }^{1,2^{*}}$, Md. Abu Zafar ${ }^{3}$ and Amir Hossain ${ }^{4}$ \\ ${ }^{1}$ Department of Aquaculture, Faculty of Fisheries, Bangladesh Agricultural University, Mymensingh, 2202, \\ Bangladesh \\ ${ }^{2}$ Department of Fisheries and Marine Bioscience, Faculty of Biological Science and Technology, Jessore \\ University of Science and Technology, Jessore, Bangladesh \\ ${ }^{3}$ Department of Aquaculture, Hajee Mohammad Danesh Science and Technology University, Dinajpur, \\ Bangladesh \\ ${ }^{4}$ Department of Fisheries Biology and Genetics, Faculty of Fisheries, Bangladesh Agricultural University, \\ Mymensingh-2202, Bangladesh
}

*Corresponding author: Abdulla-Al-Asif, Department of Aquaculture, Faculty of Fisheries, Bangladesh Agricultural University, Mymensingh 2202, Bangladesh. Phone: +8801716838294; E-mail: jessoreboyhemel@gmail.com

Received: 07 December 2017/Accepted: 21 December 2017/ Published: 28 December 2017

\begin{abstract}
Effects of different chemotherapeutics were examined against experimentally infected stinging catfish Heteropneustes fossilis. Fish were collected from a fish market in Mymensingh, acclimatized for 7 days in laboratory condition from January to February, 2016 in aquaria at Fish Clinic of Bangladesh Agricultural University, Mymensingh, experimentally injured by using forceps and knife and waited seven days for the establishment of infection. Before starting chemotherapeutic trial, it was confirmed that the fish were infected with microorganisms by clinical diagnosis in laboratory condition. They showed hemorrhages and ulcerative lesions over the infected area. A total of 80 such experimentally infected stinging catfish having average body weight of $18 \mathrm{~g}$ were used for the experiment. Two chemotherapeutics: antibiotic, Eryvet (erythromycin thiocyanate INN, sulphadiazine (NaUSP) \& trimithoprim BP) and antifungal, methylene blue were used in separate and combined treatment with three different doses of antibiotic. The same dose of methylene blue, 0.2 $\mathrm{mg} / \mathrm{l}$, was used for separate and combined treatment by antibiotic. Doses of antibiotic (Eryvet) were $0.8 \mathrm{~g} / 10 \mathrm{~kg}$ body weight of fish, $1 \mathrm{~g} / 10 \mathrm{~kg}$ body weight of fish and $1.2 \mathrm{~g} / 10 \mathrm{~kg}$ body weight of fish as lower dose, recommended dose and higher dose respectively. For combined treatment the above different doses of antibiotic and the same dose of antifungal were used. Water was exchanged regularly. The chemotherapeutic trial was conducted for 7 days and observation was continued for another 8 days to observe the effect of treatment. Combined treatment with the recommended dose of the antibiotic and methylene blue showed the best result where $90 \%$ fish were recovered. By the treatment with the higher dose of the antibiotic $70 \%$ fish were recovered. Antifungal treatment showed that $20 \%$ fish were recovered. All the fish in negative control aquarium died.
\end{abstract}

Keywords: chemotherapeutics; experimentally injured; stinging catfish

\section{Introduction}

Fish production through aquaculture is increasing day by day. But the total production is still behind the demand. Outbreak of various diseases is one of the crucial factors in fish production both in farming system and in wild condition. Diseases impact badly on fish production in different stages, such as severe mortality destroy the entire population, reduce growth and ultimately reduce the total production, disqualifying the product with 
reduced market price. A wide range of biological etiologies including virus, fungus, and especially bacteria have been associated with outbreak of diseases. Chemicals and antibiotics are important components in health management of aquatic animal, pond construction, soil and water management, improvement of natural aquatic productivity, transportation of live fish, feed formulation, manipulation of reproduction, growth promotion and processing and value addition of the final product (Subasinghe et al., 1996; GESAMP, 1997). A variety of other chemicals are also being used in aquaculture for health management of fish apart from antibiotics. They include sodium chloride, formalin, malachite green, methylene blue, potassium permanganate, hydrogen per oxide, copper compounds, glutaraldehyde and trifluralin (Plumb, 1992). Methylene blue is an organic dye that has been popular as a parasiticide and fungicide on fish. It is principally used in hatcheries rather than grow-out systems. Lengthy withdrawal period was essential following application of methylene blue because of persistent residues (Alderman, 1992). Antibiotics have been widely used in aquaculture worldwide to treat infections caused by a variety of bacterial pathogens of fish. It has been applied in aquaculture for over 50 years. Antibacterial chemotherapy is applied in aquaculture throughout the world. Although selecting the correct antibiotic and accurate dose is important factor in controlling bacterial disease, proper administration of any antibiotic for the recommended number of days is equally important. Many problems have been associated with the use of aquamedicines. Many marginal farmers face the lack of efficiency of aqua-medicines. They are not truly benefited through using the recommended dose of aqua-medicines from different pharmaceutical companies. On the other hand, if the dose of antibiotic is too low or treatment time is too short, the bacteria will not be killed or weakened enough and this greatly increases the risk of the bacteria to develop resistance to the antibiotic. When bacteria become resistant to a specific antibiotic, even high concentrations of that drug will not be effective. Decreased efficacy has been documented in many antimicrobial drugs regardless of their mechanism of action (Dixon, 1994). The objectives of the present study were to understand the effect of selected chemotherapeutics against experimentally infected Heteropneustes fossilis and to determine the dose, dosage, and methods of their application.

\section{Materials and Methods}

\subsection{Experimental fish}

Stinging catfish Heteropneustes fossilis of average body weight of $18 \mathrm{~g}$ were collected from the Mechua Bazar fish market in Mymensingh. The fish were acclimatized for 7 days in laboratory condition at Fish Clinic of Bangladesh Agricultural University, Mymensingh.

\subsection{Experimental injury}

The acclimatized fish were experimentally injured by using forceps and knife at a dorso-lateral place, ventrolateral portion of the caudal region, ventral region and on the dorsal surface of the head (Figure 1). The fish were kept in the same aquaria and waited for seven days for formation of lesions. After the establishment of infection, 80 such experimentally infected fish were selected for chemotherapeutic treatment.
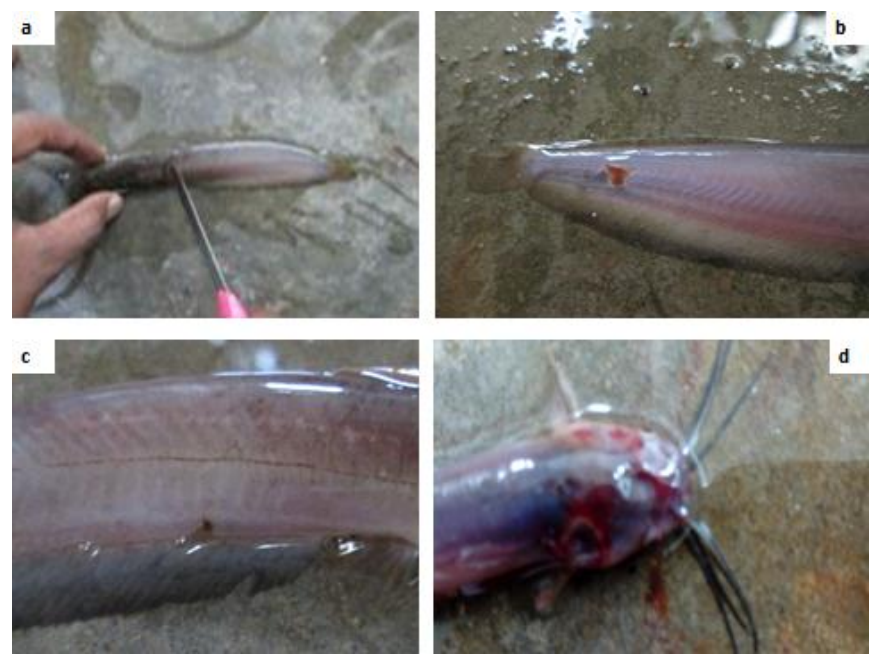

Figure 1. Experimental injury on the (a) dorso-lateral region (b) ventro-lateral portion in the caudal region (c) on the ventral region (d) on the dorsal surface of the head of stinging catfish, Heteropneustes fossilis. 


\subsection{Clinical diagnosis}

For primary detection of the establishment of infection, following general clinical symptoms were investigated. The observation were, presence of any external hemorrhage; presence of any superficial and or ulcerative lesion in the experimentally injured place; darkening of body color; condition of any exophthalmia; loss or rottening of any fin rays; any cork screw or vertical swimming; any abnormal feeding tendency; and any sluggish movement or frequent rest.

\subsection{Chemotherapeutics used}

The antibiotic, Eryvet (Figure 2a) was used in treating the experimental infections. The trade name was Eryvet; composition was Erythromycin thiocyanate INN, sulphadiazine (NaUSP) and trimithoprim BP; name of the company was ACI Animal Health, ACI Limited. The recommended dose was $1 \mathrm{~g} / 10 \mathrm{~kg}$ fish for 7 days. Methylene blue, the antifungal (Figure 2b) was also used in this experiment.
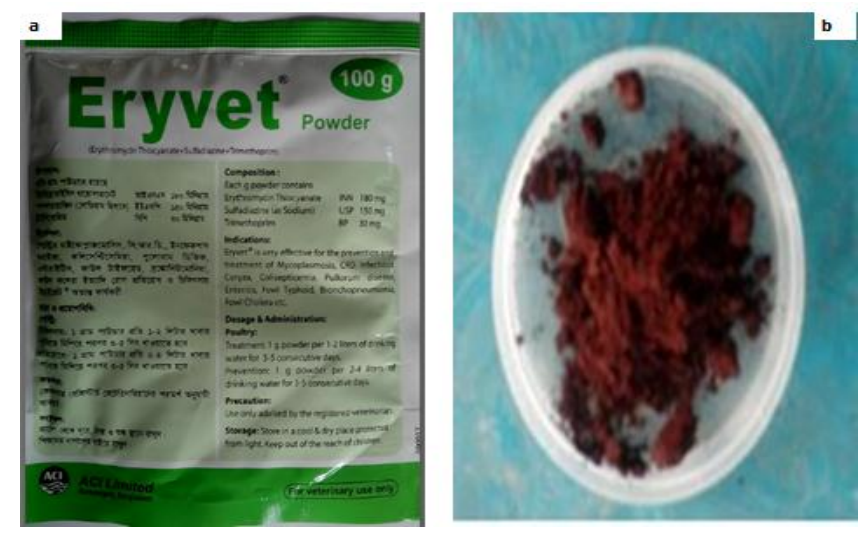

Figure 2. (a) Eryvet the antibiotic (b) Methylene blue, the antifungal, used in the experiment.

\subsection{Experimental setup}

The water re-circulatory system in the wet laboratory of the Faculty of Fisheries, Bangladesh Agricultural University, Mymensingh, was consisted of 12 rectangular glass aquaria of 40 1iter capacity, 5 drums, 1 pump and one overhead tank. Water was picked up into the overhead tank by pump. Aquaria were filled up by the water of overhead tank through downward pipe. When aquaria were filled up, water was passed through collection pipe to ultra-violet tube light complex. Then the water was reserved in the plastic drum. Drum water was picked up into the over head tank by pump (Figure 3). Freshwater from underground deep pump was added to the re-circulatory system as and when needed to fill up the loss due to evaporation. The trials were conducted in eight separate aquaria. Antifungal treatment was given in one aquaria, three aquaria were treated with antibiotic, the next three aquaria were treated with the combination of antibiotic and antifungal, and rest aquaria was selected as negative control. The aquaria with the above chemotherapeutics were designed as Section-A, Section-B, Section-C and Section-D, as follows.

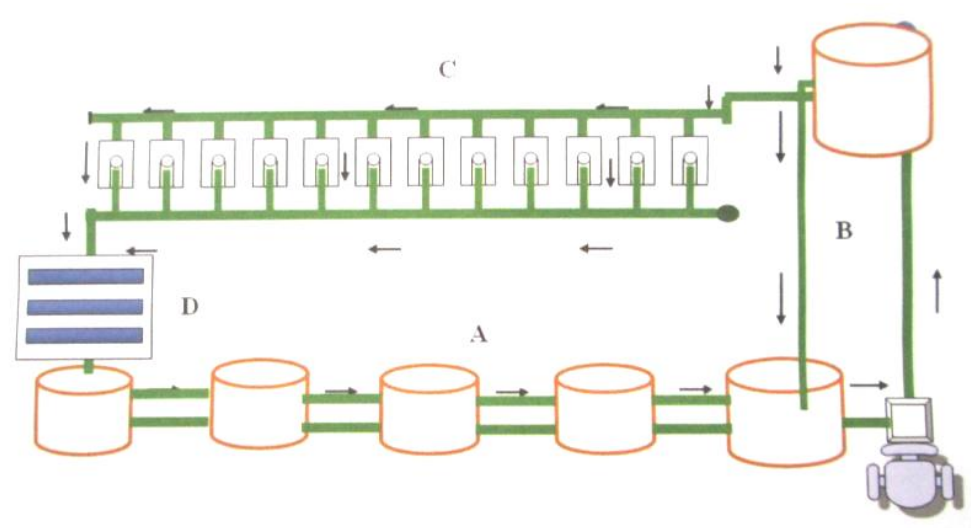

Figure 3. Layout of the re-circulatory system used for the experimentally injured catfish. A. five plastic drums; B. motor and overhead tank; C. downward pipeventilated to each aquarium and the collection pipe; D. ultra violet tube light complex. 


\subsubsection{Antifungal treatment (Section A)}

In section-A, the aquarium number 1 was treated with the antifungal, methylene blue, at a dose of $0.2 \mathrm{mg} / \mathrm{l}$ water and the fish were intubated with $0.5 \mathrm{ml}$ of sterile distilled water, once daily for 7 days.

\subsubsection{Antibiotic treatment (Section B)}

In Section-B, the aquarium number 2 was supplied with the antibiotic Eryvet at a dose, lower than the recommended dose, $0.8 \mathrm{~g} / 10 \mathrm{~kg}$ fish. In Section-B, the aquarium number 3 was supplied with the antibiotic Eryvet at the recommended dose, $1 \mathrm{~g} / 10 \mathrm{~kg}$ fish. In Section-B, the aquarium number 4 was supplied with the antibiotic Eryvet at a dose, higher than the recommended dose, $1.2 \mathrm{~g} / 10 \mathrm{~kg}$ fish.

\subsubsection{Combination of antifungal and antibiotic (Section $\mathrm{C}$ )}

In Section-C, the aquarium number 5 was supplied with a combined treatment of the antibiotic, Eryvet, at a dose, lower than the recommended dose, $0.8 \mathrm{~g} / 10 \mathrm{~kg}$ fish and the antifungal, methylene blue, at a dose of 0.2 $\mathrm{mg} / \mathrm{l}$ of water. In Section-C, the aquarium number 6 was supplied with a combined treatment of the antibiotic Eryvet at the recommended dose, $1 \mathrm{~g} / 10 \mathrm{~kg}$ fish and the antifungal, methylene blue at a dose of $0.2 \mathrm{mg} / \mathrm{lof}$ water. In Section-C, the aquarium number 7 was supplied with a combined treatment of the antibiotic Eryvet at a dose, higher than the recommended dose, $1.2 \mathrm{~g} / 10 \mathrm{~kg}$ fish and the antifungal, methylene blue, at a dose of 0.2 $\mathrm{mg} / \mathrm{l}$ of water.

\subsubsection{Negative control (Section D)}

In Section D, the aquarium number 8 was not mixed with any antifungal and the fish were intubated not with any antibiotic but with $0.5 \mathrm{ml}$ of sterile distilled water, once daily for 7 days. Ten fish were released in each aquarium. Thus, in eight aquaria, $10 \times 8=80$ fish were used. Average body weight of fish was $18 \mathrm{~g}$ (Table 1). Medicinal trial period was 7 days and, after that period, more 8 days were for observation of the treatment result. Thus total experimental period was one month (Table 2).

Table 1. The average body weight of each of ten fish in eight different aquaria.

\begin{tabular}{lllllllll}
\hline Aquarium number & Section-A & Section-B & & \multicolumn{3}{l}{ Section-C } & \multicolumn{2}{l}{ Section-D } \\
\cline { 2 - 8 } & $\mathbf{1}$ & $\mathbf{2}$ & $\mathbf{3}$ & $\mathbf{4}$ & $\mathbf{5}$ & $\mathbf{6}$ & $\mathbf{7}$ & $\mathbf{8}$ \\
\hline Individual body weight $(\mathrm{g})$ & 15 & 14 & 16 & 16 & 14 & 17 & 18 & 17 \\
& 15 & 14 & 16 & 17 & 14 & 18 & 19 & 18 \\
& 15 & 14 & 17 & 17 & 14 & 19 & 19 & 18 \\
& 16 & 15 & 17 & 17 & 15 & 19 & 19 & 18 \\
& 17 & 16 & 18 & 18 & 15 & 20 & 19 & 18 \\
& 17 & 16 & 18 & 18 & 16 & 20 & 20 & 19 \\
& 18 & 17 & 18 & 18 & 17 & 21 & 21 & 20 \\
Total body weight $(\mathrm{g})$ & 18 & 17 & 20 & 19 & 17 & 21 & 21 & 20 \\
Average body weight $(\mathrm{g})$ & 19 & 18 & 20 & 20 & 18 & 22 & 22 & 21 \\
& 17 & 19 & 20 & 20 & 20 & 23 & 22 & 21 \\
\end{tabular}

Table 2. Different stages of the experiment and its duration.

\begin{tabular}{ll}
\hline Experimental stage & Duration (days) \\
\hline Acclimatization & 7 \\
Experimental injury & 1 \\
Post injured infection establishment period & 7 \\
Drug treatment period & 7 \\
Period of observation of result & 8 \\
Total & 30 \\
\hline
\end{tabular}

\subsection{Calculation and application of chemotherapeutics}

2.6.1. Antifungal (Methylene blue) (section A)

\subsubsection{Aquarium number 1}

Aquarium contained 30 liter of water. Dose of methylene blue $=0.2 \mathrm{ppm}(0.2 \mathrm{mg} / \mathrm{l})$ for prolong treatment. Total amount of methylene blue needed for aquarium $=(0.2 \times 30) \mathrm{mg}=6 \mathrm{mg}$. Every $6 \mathrm{mg}$ methylene blue was 
weighed in an electric balance and put in an aquarium for 7 days. Everyday 50 percent water was changed and addition of methylene blue was adjusted after water change.

\subsubsection{Antibiotic (Eryvet) (section B)}

\subsubsection{Preparation of antibiotic}

At first $12.8 \mathrm{mg}, 18 \mathrm{mg}, 21.6 \mathrm{mg}$ antibiotic was weighed in an electric balance and taken in three separate cleaned petridishes. Then $5 \mathrm{ml}$ distilled water was added to the petridish to prepare $5 \mathrm{ml}$ antibiotic solution. This $5 \mathrm{ml}$ antibiotic solution was used for 10 fish. So, each fish was treated with $0.5 \mathrm{ml}$ antibiotic solution. Fish was taken out from the aquarium by a scoop net and the suspension intubated orally. After 10 seconds of intubation fish was released in the aquarium. Antibiotic treatment was given once daily for 7 days.

\subsubsection{Aquarium number 2}

Number of total fish used for antibiotic treatment was 10.Selected lower than the recommended dose: $0.8 \mathrm{~g} / 10$ $\mathrm{kg}$ body weight for 7 days. Average body weight of fish was $16 \mathrm{~g}$. Total body weight of $10 \mathrm{fish}=160 \mathrm{~g}$. Total amount of antibiotic required for 10 fish for 1 day $=0.8 \times 160 \times 1000 / 10000=12.8 \mathrm{mg}$. So, each fish required $1.28 \mathrm{mg}$ antibiotic each day.

\subsubsection{Aquarium number 3}

Number of total fish used for antibiotic treatment was 10. Selected recommended dose: $1 \mathrm{~g} / 10 \mathrm{~kg}$ body weight for 7 days. Average body weight of fish was $18 \mathrm{~g}$. Total body weight of 10 fish $=180 \mathrm{~g}$. Total amount of antibiotic required for $10 \mathrm{fish}=1 \times 180 \times 1000 / 10000=18 \mathrm{mg}$. So, each fish required $1.8 \mathrm{mg}$ antibiotic each day.

\subsubsection{Aquarium number 4}

Number of total fish used for antibiotic treatment was 10. Selected higher than the recommended dose: $1.2 \mathrm{~g} / 10$ $\mathrm{kg}$ body weight for 7 days. Average body weight of fish was $18 \mathrm{~g}$. Total body weight of $10 \mathrm{fish}=180 \mathrm{~g}$. Total amount of antibiotic required for $10 \mathrm{fish}=1.2 \times 180 \times 1000 / 10000=21.6 \mathrm{mg}$. So, each fish required $2.16 \mathrm{mg}$ antibiotic each day.

\subsubsection{Combination of antifungal and antibiotic (section C)}

\subsubsection{Preparation of antifungal (Methylene blue)}

Each aquarium contained 30 liter water. Dose of methylene blue $=0.2 \mathrm{ppm}(0.2 \mathrm{mg} / \mathrm{l})$ for prolong treatment. Total amount of methylene blue needed for aquarium $=(0.2 \times 30) \mathrm{mg}=6 \mathrm{mg}$.

$6 \mathrm{mg}$ methylene blue was weighed in an electric balance and put in Aquarium-5, Aquarium-6, Aquarium-7 respectively for 7 days. Everyday 50 percent water was changed and chemotherapeutics were adjusted after water change.

\subsubsection{Preparation of antibiotic}

At first $12.8 \mathrm{mg}, 20 \mathrm{mg}, 24 \mathrm{mg}$ antibiotic were weighed in an electric balance and taken in three separate cleaned petridishes. Then $5 \mathrm{ml}$ distilled water was added to the petridish to prepare $5 \mathrm{ml}$ antibiotic solution. This $5 \mathrm{ml}$ antibiotic solution was used for $10 \mathrm{fish}$. So, each fish was treated with $0.5 \mathrm{ml}$ antibiotic solution. Antibiotic solution was used for treatment as; the amount of $0.5 \mathrm{ml}$ antibiotic suspension was taken in a syringe. Fish was taken out from the aquarium by a scoop net and the suspension intubated orally. After 10 seconds of intubation fish was released in the aquarium. Antibiotic treatment was given once daily for 7 days.

\subsubsection{Antibiotic (Eryvet)}

\subsection{Aquarium number 5}

Number of total fish used for antibiotic treatment was 10. Selected lower than the recommended dose $0.8 \mathrm{~g} / 10$ $\mathrm{kg}$ body weight for 7 days.Average body weight of fish was $16 \mathrm{~g}$. Total body weight of $10 \mathrm{fish}=160 \mathrm{~g}$. Total amount of antibiotic required for $10 \mathrm{fish}=0.8 \times 160 \times 1000 / 10000=12.8 \mathrm{mg}$. So, each fish required $1.28 \mathrm{mg}$ antibiotic each day.

\subsection{Aquarium number 6}

Number of total fish used for antibiotic treatment was 10 . Selected recommended dose: $1 \mathrm{~g} / 10 \mathrm{~kg}$ body weight for 7 days. Average body weight of fish was $20 \mathrm{~g}$. Total body weight of 10 fish $=200 \mathrm{~g}$. Total amount of antibiotic required for $10 \mathrm{fish}=1 \times 200 \times 1000 / 10000=20 \mathrm{mg}$. So, each fish required $2 \mathrm{mg}$ of antibiotic each day. 


\subsection{Aquarium number 7}

Number of total fish used for antibiotic treatment was 10. Selected higher than the recommended dose, $1.2 \mathrm{~g} / 10$ $\mathrm{kg}$ body weight for 7 days. Average body weight of fish was $20 \mathrm{~g}$. Total body weight of $10 \mathrm{fish}=200 \mathrm{~g}$. Total amount of antibiotic required for $10 \mathrm{fish}=1.2 \times 200 \times 1000 / 10000=24 \mathrm{mg}$. So, each fish required $2.4 \mathrm{mg}$ antibiotic each day.

\section{Results}

\subsection{Temperature of the re-circulatory system}

During the study period the temperature of the re-circulatory system were ranged from $17^{\circ} \mathrm{C}$ to $25^{\circ} \mathrm{C}$. The average temperature was $21.5^{\circ} \mathrm{C}$ (Figure 4).

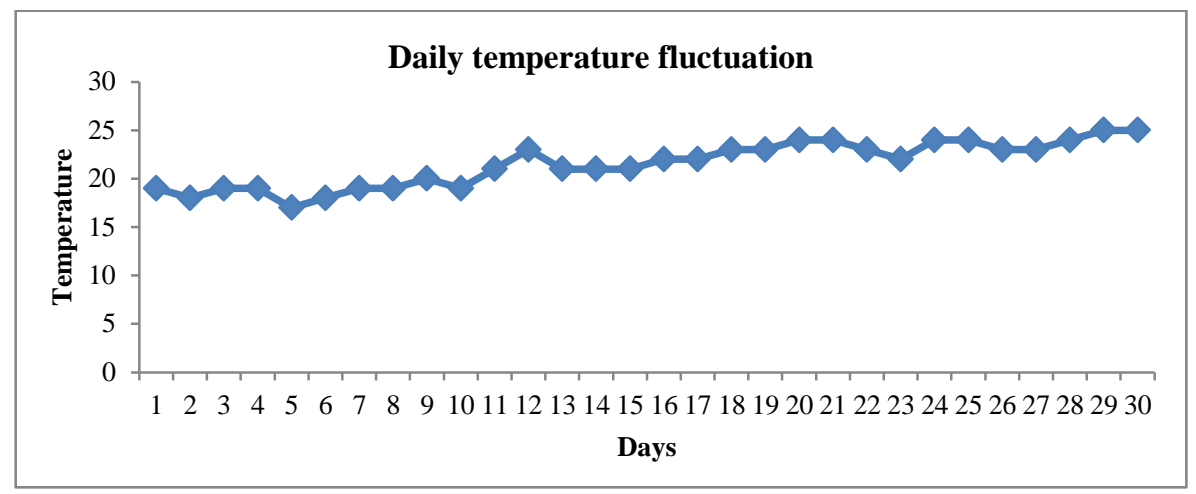

Figure 4. Daily temperature fluctuation during the experimental period.

\subsection{Gross clinical features of the experimentally infected fish}

Experimentally infected stinging catfish Heteropneustes fossilis showed the following features after 7 days of artificial injury. Reddish lesion on the dorsal surface of the head (Figure 5); cottony appearance on the dorsal region (Figure 5); lesion on the ventro-lateral portion in the caudal region (Figure 5); lesion on the ventral region (Figure 6); lesion on the fin in the caudal region (Figure 6); hemorrhagic lesion on dorsal surface in the caudal region (Figure 6); blackish spot on the ventral region(Figure 6); cottony appearance on the dorso-lateral region (Figure 6).
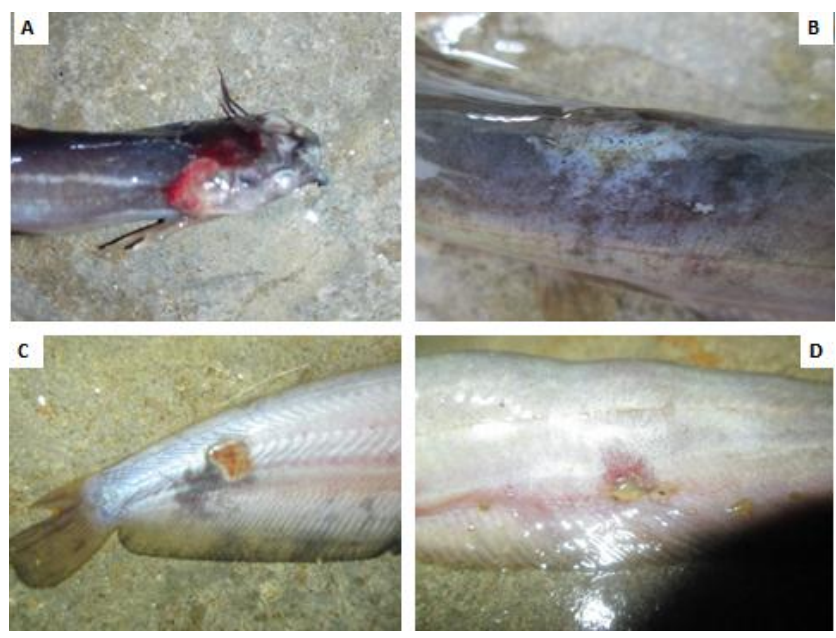

Figure 5. (A) Reddish lesion on the dorsal surface of the head; (B) Cottony appearance on the dorsal region; (C) Lesion on the ventro-lateral portion in the caudal and (D) Lesion on the ventral region of experimental fish. 

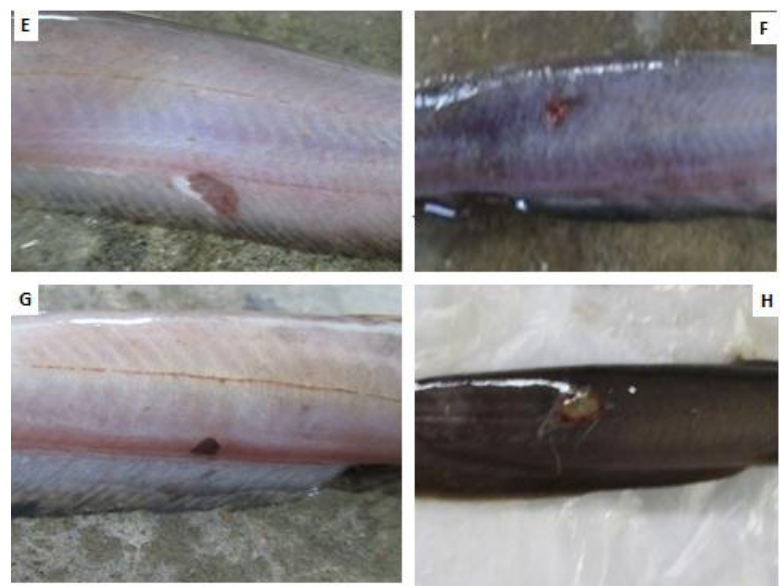

Figure 6. (E) Lesion on the fin in the caudal region (F) Hemorrhagic lesion on dorsal surface in the caudal region (G) Blackish spot on the ventral region and $(\mathrm{H})$ Cottony appearance on the dorso-lateral region of experimental fish.

\subsection{Results after chemotherapeutic treatment}

With the treatment of antifungal, mythelene blue two fish were cured, three fish were not recovered and five fish were died during the experiment (Figure 7). Results found after treatment with chemotherapeutics are shown in Table 3.
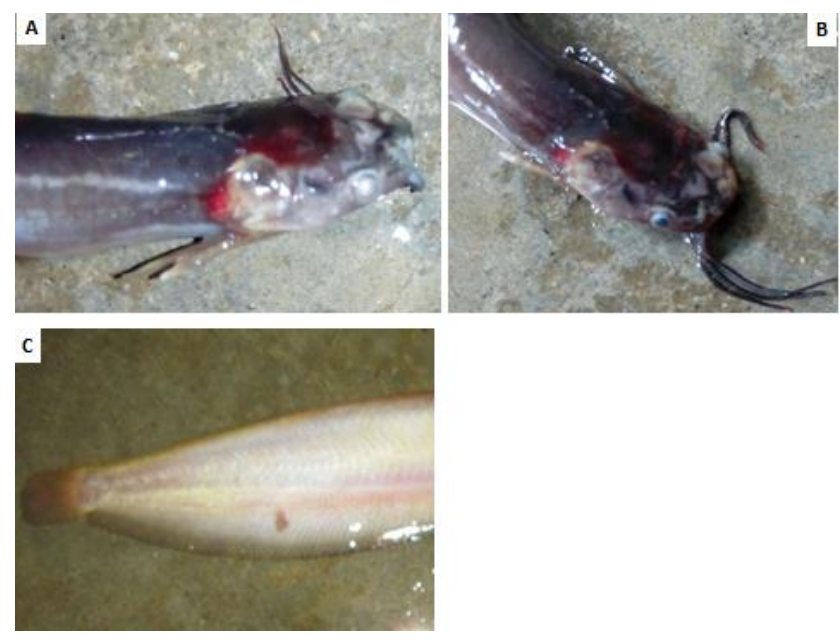

Figure 7. (A) No significant difference found at the seventh day of treatment; (B) Lesion present in the dorsal surface of the head at the end of the experiment; (C) Cured fish at the end of the experimental period.

With the treatment of antibiotic, Eryvet, at lower than the recommended dose three fish were not recovered but were alive and seven other fish were died during experiment (Figure 8).
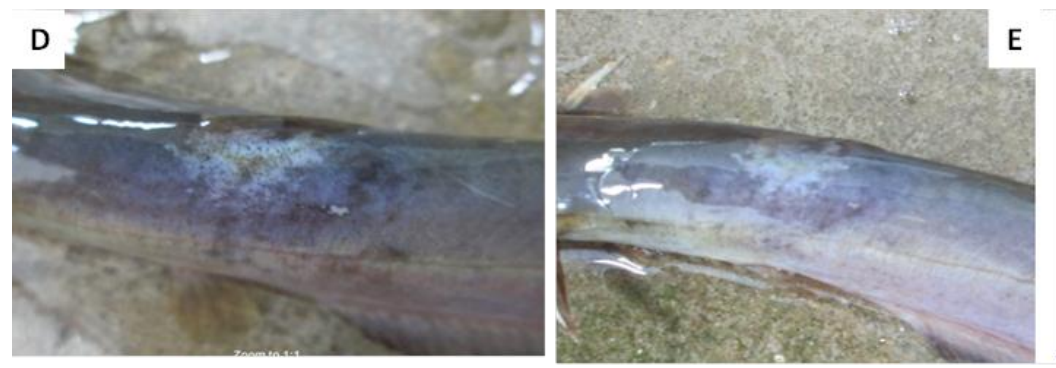

Figure 8. (D) Cottony appearance present at the seventh day of treatment; (E) Improvement of infected region at the end of experimental period. 
With the treatment of antibiotic, Eryvet, at recommended dose, five fish were cured, one fish was not recovered and other four fish were died during experiment (Figure 9).
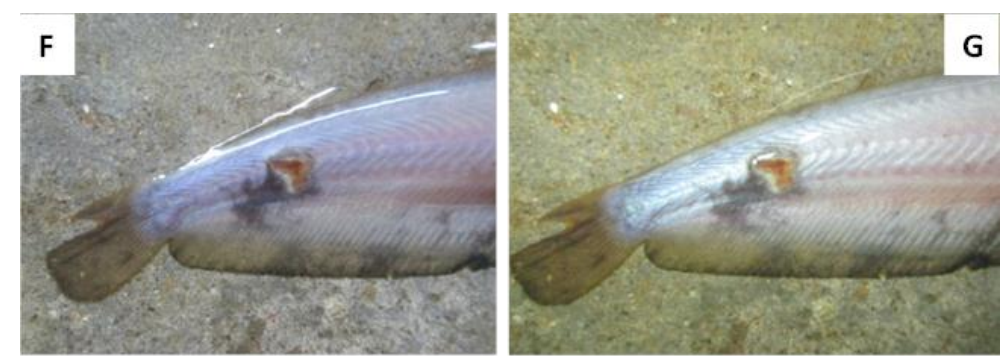

Figure 9. (F) Improvement of infected region at seventh day of the treatment period; (G) Not recovery of infected region at the end of the experimental period.

With higher than the recommended dose of antibiotic, Eryvet, seven fish were cured, one fish was not recovered and two fish were died during experiment (Figure 10).
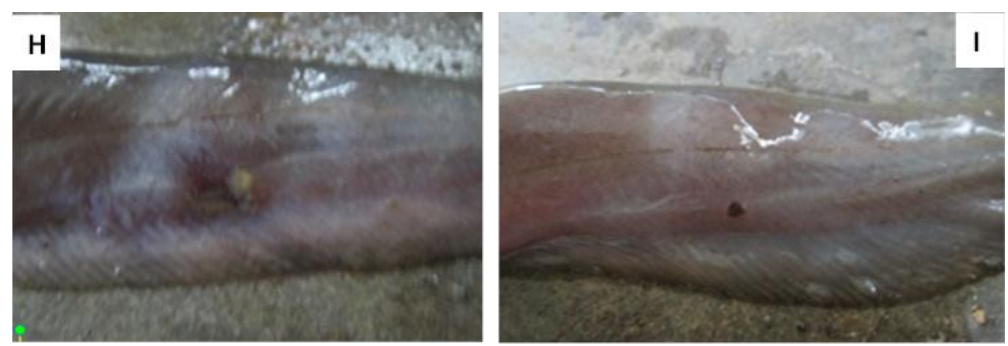

Figure 10. (H) Improvement of infected region at seventh day of the treatment period; (I) Cured fish at the end of the experimental period.

With antifungal and lower than the recommended dose of antibiotic, Eryvet, four fish were cured, four fish were not recovered and other two fish died during experiment (Figure 11).
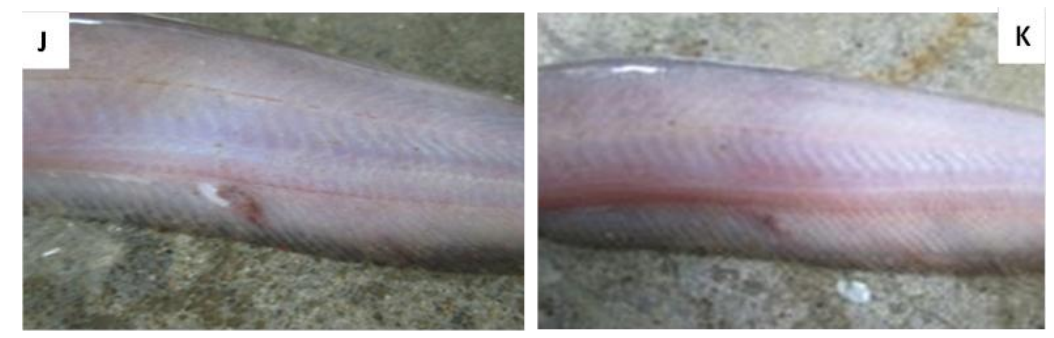

Figure 11. (J) Improvement of infected region at seventh day of the treatment period; (K) Cured fish at the end of the experimental period.

With antifungal and recommended dose of antibiotic, Eryvet, nine fish were cured, and one fish died during experiment (Figure 12).
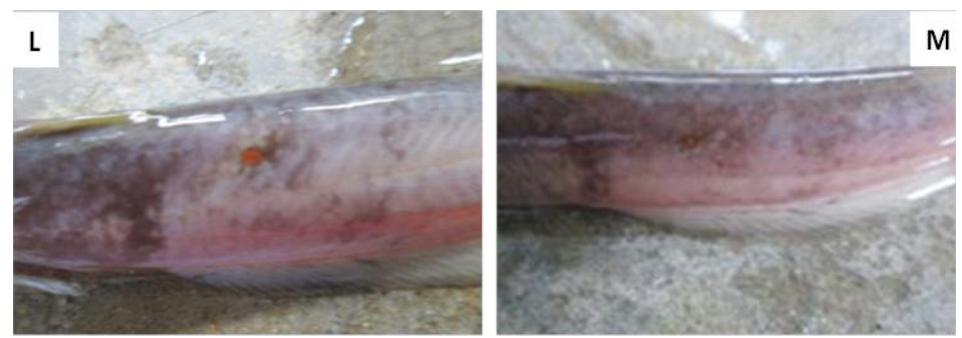

Figure 12. (L) Improvement of infected region at seventh day of the treatment period; (M) Cured fish at the end of the experimental period. 
With antifungal and higher than the recommended dose of antibiotic, Eryvet, nine fish were cured, and one fish died during experiment (Figure 13).
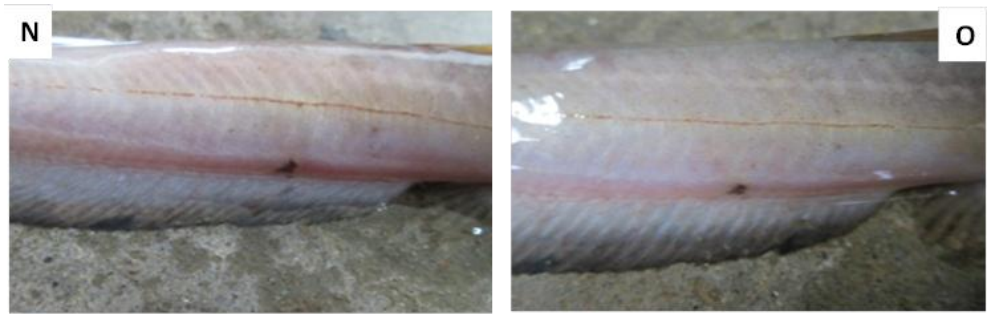

Figure 13. (N) Improvement of infected region at seventh day of the treatment period; (O) Cured fish at the end of the experimental period.

In the negative control all of the ten fish of the experiment died (Figure 14).
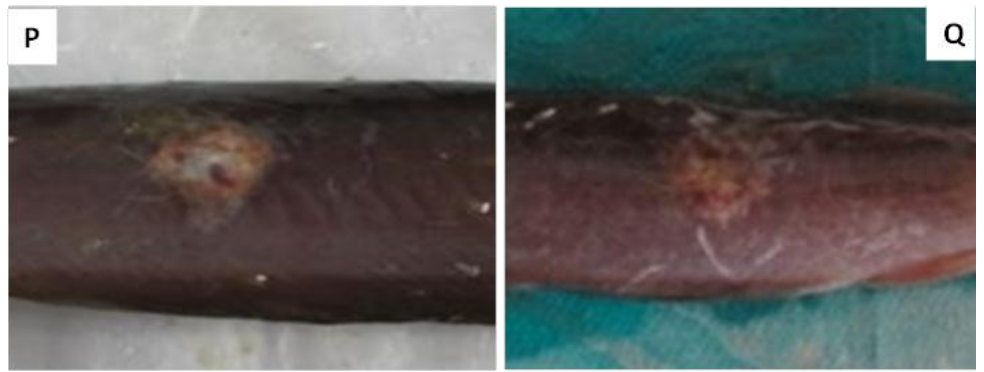

Figure 14. (P) Development of infected region at seventh day of the treatment period; (Q) Dead fish at the fifth day of observation.

Table 3. Effects of chemotherapeutics on experimentally infected Heteropneustes fossilis.

\begin{tabular}{|c|c|c|c|c|c|c|}
\hline Chemotherapeutics & Selected dose & $\begin{array}{l}\text { No. of fish } \\
\text { treated }\end{array}$ & $\begin{array}{l}\text { No. of } \\
\text { fish } \\
\text { cured }\end{array}$ & $\begin{array}{l}\text { No. of fish not } \\
\text { recovered }\end{array}$ & $\begin{array}{l}\text { No. of } \\
\text { fish dead }\end{array}$ & $\begin{array}{l}\text { Percentage of } \\
\text { recovery }\end{array}$ \\
\hline $\begin{array}{l}\text { Antifungal (Mythelene } \\
\text { Blue) }\end{array}$ & $0.2 \mathrm{mg} / \mathrm{l}$ & 10 & 2 & 3 & 5 & 20 \\
\hline \multirow[t]{3}{*}{ Antibiotic (Eryvet) } & Lower & 10 & 0 & 3 & 7 & 0 \\
\hline & Recommended & 10 & 5 & 1 & 4 & 50 \\
\hline & Higher & 10 & 7 & 0 & 3 & 70 \\
\hline Antifungal & Lower & 10 & 4 & 4 & 2 & 40 \\
\hline+ & Recommended & 10 & 9 & 0 & 1 & 90 \\
\hline Antibiotic & Higher & 10 & 9 & 0 & 1 & 90 \\
\hline Negative Control & No Treatment & 10 & 0 & 0 & 10 & 0 \\
\hline
\end{tabular}

\subsection{Cumulative mortality}

At the end of experiment lowest cumulative mortality, $10 \%$ was found for recommended and higher than the recommended dose of antibiotic with antifungal (CRD, CHD) treatment. For the combined treatment of antibiotic lower than the recommended dose and antifungal (CLD) showed $20 \%$ cumulative mortality. At the rate of $30 \%$ cumulative mortality was found for higher than the recommended dose of antibiotic (AHD). The treatment of recommended dose of antibiotic (ARD), $40 \%$ cumulative mortality was found. Only antifungal treatment, 50\% cumulative mortality was found. For lower than the recommended dose of antibiotic (ALD) treatment, $70 \%$ cumulative mortality was found. The highest cumulative mortality was found for negative control, where all the fish were died and their cumulative mortality was $100 \%$. Different cumulative mortality of treated fish against selected chemotherapeutics are shown in Figure 15. 


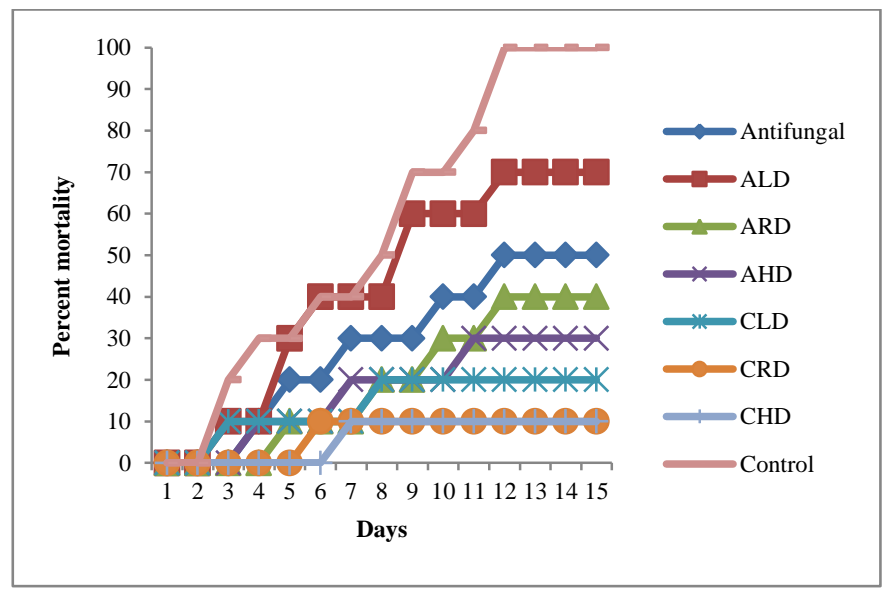

Figure 15. Cumulative mortality of treated fish against selected chemotherapeutics, by which the result, either cured or not recovered but also not died at the end of the experimental period, was understood.

\section{Discussion}

Commonly found traditional chemotherapeutics for disease control of fish are antibiotics, lime, salt, potassium permanganate, sumithion, melathion, formalin, bleaching powder, malachite green, methylene blue, and copper sulphate. Some previous studies also revealed the similar reports about the use of chemicals in Bangladesh aquaculture (Phillips, 1996; Brown and Brooks, 2002; Faruk et al., 2005). According to, Rahman et al. (2016) and Ali et al. (2016) in the culture condition fishes were frequently affected by bacterial pathogen. Fungus attacked at the infected region as secondary invader. Different antibiotic and antifungal agents are useful to prevent bacterial and fungal disease. To establish the accurate dose, dosage and treatment method of commonly used antibiotic, Eryvet and antifungal, methylene blue, they were selected for the experiment at laboratory condition. Chemotherapeutics reduce the level of infection which either prevent multiplication of pathogen or retard their growth and the fish can overcome the disease (Olah and Farks, 1978; Srivastata, 1978; Zahura, 2001). The dose of chemotherapeutics in the present study differed from some of the previous study but the modes of action of the chemotherapeutics were found to be very similar. In any case, treatments using antibiotic have to be administrated at the effective dosage and during enough time to ensure elimination of bacteria (De Kinkelin et al., 1986). The present study was carried out to justify the recommended dose and method of application of particular chemotherapeutics. Some variation was found between the information leaflet and packed indication. Neither the sellers nor the farmers or extension workers had clear idea about the ingredient of pharmaceutical companies nor were they using those without hesitation.Little is known about the fate of unused antibiotics or their effect on the environment (Rahman et al., 2015a; Rahman et al., 2015b; Shabuj et al., 2015 and Yeasmin et al., 2015). Obviously, the potential exists for the antibiotics to affect adversely natural bacterial communities. Studies of freshwater salmonid farms by Austin (1985) showed that bacterial numbers decreased in effluent during chemotherapy. Moreover, it took many weeks for compounds such as oxytetracycline to be broken down, depending upon temperature, oxygen and light levels (Jacobson and Berglind, 1988; Samuelson, 1989 and Neowajh et al., 2015).

In the present study, methylene blue was run to prevent secondary infection caused by fungus. It was used with antibiotic combinedly at a dose of $0.2 \mathrm{mg} / \mathrm{l}$ as prolonged treatment. It showed the best result (90\% recovery of fish). The relevant results were found by the study of Sharmin et al. (2016); Hossain et al. (2016); Monir et al. (2015); Chowdhury et al. (2015); Ahmed et al. (2015); Hasan et al. (2015) and Borty et al. (2016). Scott and Warren (1964) used $2 \mathrm{ppm}$ concentration of methylene blue for complete destruction of fungal hyphae within 7 days treatment. Rahman et al. (2017) found the same result at the species of L. bata. Roberts (1993) found that $0.25 \mathrm{ppm}$ of methylene blue was required to kill Saprolegnia parasitica. In the present study it was found that $0.2 \mathrm{mg} / \mathrm{l}$ mythelene blue was helpful to prevent fungal infection in combination with antibiotic, Eryvet. Rahman and Chowdhury (1999) conducted trials of chemotherapy to control the ulcer disease-affecting catfish as a case study. The best result was obtained by a successive bath in 1-2\% NaCI suspension and subsequent oral treatment with commercial erythromycine at a dose of $75 \mathrm{mg}$ per $\mathrm{kg}$ body weight of fish for 5 days. Haque $e t$ al. (2014) observed the effectiveness of antibiotic, erythromycin, reducing the bacterial load in rohu fish under artificial culture condition in the laboratory. They resulted that $2 \mathrm{gm} / \mathrm{kg}$ erythromycin in diet, twice daily is potential antibiotic to reduce bacterial load in fish and can be used commercially for maintaining the fish health in aquarium condition. The present study was conducted very carefully during uses of chemotherapeutics. 
Combined use of chemotherapeutics: antibiotic and methylene blue treatment showed best results (90\% recovery of fish). Single antibiotic (Eryvet) showed good results at higher dose (70\% recovery of fish). Single methylene blue showed bad results (20\% recovery of fish).It is suggested that combined treatment of antibiotic, Eryvet at a dose of $1 \mathrm{~g} / 10 \mathrm{~kg}$ body weight of fish for 7 days once daily and antifungal, methyleene blue at a dose of $0.2 \mathrm{mg} / \mathrm{l}$ water for 7 days should be used for effective result. However, field level experimental trials should be conducted before its implementation.

\section{Conclusions}

For successful aquaculture operation selecting the correct chemotherapeutic is an important first step in controlling infection, proper administration of any chemotherapeutic for the recommended days is equally important. Generally, lesions occur in the fish body due to bacterial infection which may be cured by antibiotic treatment. But sometimes, as a secondary invader fungus may also be found on the lesion area. Thus, an antifungal drug use together with antibiotics should be effective measure. In treating both bacterial and fungal infection, use of mythelene blue is recommended widely. In the present study use of methylene blue together with the antibiotic showed the best result. Only single use of antibiotic did not show the best result. Obviously without antibiotic, use of methylene blue also did not show the best result. So, in the case of experimentally infection of at least stringing catfish, an effective antibiotic treatment like Eryvet together with an anti-fungal drug mythelene blue is recommended.

\section{Conflict of interest}

None to declare.

\section{Acknowledgement}

The research team would like to acknowledge and thanks to Mr. Rabi Talukder, Deputy Sales Manager, ACI Animal Health, ACI limited for his tremendous support and inspiration to conduct this research and promotion of Eryvet powder.

\section{References}

Ahmed GU, MN Alam and MM Rahman, 2015. Impact of aqua drugs and chemicals on the recoveries of fish diseases and total fish production in Sherpur region of Bangladesh. Asian J. Med. Biol. Res., 1: 600-606.

Alderman DJ, 1992. Malachite green and alternatives as therapeutic agents.European Aquaculture Society Special Publications, 16: 235-244.

Ali MM, AA Asif, MAI Shabuj, O Faruq, S Vaumik, BMN Sharif and MA Zafar, 2016. Technology of artificial breeding of catfish species in the hatcheries in Jessore Region, Bangladesh. Int. J. Fish. Aqua. Stud., 4: 180188.

Austin B, 1985. Antibiotic pollution from fish farms: effects on aquatic microflora. Microbiological Science, 2: 113-117.

Borty SC, F Rahman, AKMA Reza, MS Khatun, ML Kabir, MH Rahman and MS Monir, 2016. Isolation, molecular identification and antibiotic susceptibility profile of Aeromonas hydrophila from cultured indigenous Koi (Anabus testudineus) of Bangladesh. Asian J. Med. Biol. Res., 2: 332-340.

Brown D and A Brooks, 2002. A survey of disease; impact and awareness in pond aquaculture in Bangladesh, the Fisheries and Training Extension Project Phase11. In: Arther JR, MJ Phillips, RP Subasinghe, MB Reantaso and LH MacRae (Editors), Primary Aquatic Animal Health Care in Rural, Small Scale and Aquaculture Development. FAO Fisheries Technical Paper No. 406.pp. 85-93.

Chowdhury AA, MS Uddin, S Vaumik and AA Asif, 2015. Aqua drugs and chemicals used in aquaculture of Zakigonj upazilla, Sylhet. Asian J. Med. Biol. Res., 1: 336-349.

De Kinkelin P, C Michel and P Ghittino, 1986. Precis de pathologie des poisons. INRA/OIE, Paris, France.pp. 360.

Dixon BA, 1994. Antibiotics resistance of bacterial fish pathogens. Journal of World Aquaculture Society, 25: 60-63.

Faruk MAR, Sultana and MB Kabir, 2005. Use of Chemicals in aquaculture activities in Mymensingh area, Bangladesh. Bangladesh Journal of Fisheries Research, 29: 110.

GESAMP 1997. Joint Group of Experts on the Scientific Aspects of Marine Environmental Protection. Towards safe and effective use of chemicals in coastal aquaculture. IMO/ FAO/ UNESCO/ IOC// WMO/ WHO/ IAEA/ UN/ UNEP. pp. 40-65. 
Haque SA, MS Rez, MR Sharker, MM Rahman and MA Islam, 2014. Effectiveness of erithromycine in reducing the bacterial load in rohu fish (Labeo rohita) under laboratory culture condition. Journal of Coastal Life Medicine, 2: 259-263.

Hasan MT, GU Ahmed, MM Rahman and MN Alam, 2015. Study on the effect of aquaculture-drugs and chemicals on health and production of prawn (Macrobrachium rosenbergii) in Narail, Bangladesh. Asian J. Med. Biol. Res., 1: 89-94.

Hossain S, MI Miah, MS Islam and M Shahjahan, 2016. Changes in hepatosomatic index and histoarchitecture of liver in common carp exposed to organophosphate insecticide sumithion. Asian J. Med. Biol. Res., 2: 164-170.

Monir MS, MAU Doulah, MK Rahman, JN Akhter and MR Hossain, 2015. Effect of cypermethrin on the histoarchitecture of gills and liver of a freshwater catfish, Pangasianodon hypophthalmus. Asian J. Med. Biol. Res., 1: 641-647.

Neowajh S, MMM Hossain, I Kholil, SN Mona and S Islam, 2015. Potentiality of selected commercial antibiotics challenged with Aeromonas sp. Immunology and Infectious Disease, 3: 11-15.

Olah J and J Farks, 1978. Effects of temperature, pH, antibiotics, formalin and malachite green on the growth and survival of Saprolegnia and Achlya parasitic on fish. Aquaculture, 13: 273-288.

Phillips M, 1996. The use of chemicals in carp and shrimp aquaculture in Bangladesh, Cambodia, Lao PDR, Nepal, Pakistan, Sri Lanka and Vietnam. In: JR Arthur, CR Lavilla- Pitogo and RP Subasinghe (Editors), Use of Chemicals in Aquaculture in Asia. Southeast Asian Fisheries Development Center, Aquaculture Department Tigbauan, Iloilo, Philippines. pp. 75-84.

Plumb JA, 1992. Disease control in aquaculture. In: LM Shariff, RP Subasinghe and JR Arthur (Editors), Disease in Asian Aquaculture. Fish Health Section of the Asian Fisheries Society, Manila, Philippines, pp. 317.

Rahman KMM and MN Sarowar, 2016. Molecular characterization of oomycetes from fish farm located in Mymensinghsadar during summer. Asian J. Med. Biol. Res., 2: 236-246.

Rahman MA, MH Rahman, SM Yeasmin, AA Asif and D Mridha, 2017. Identification of causative agent for fungal infection and effect of disinfectants on hatching and survival rate of bata Labeobata larvae. Adv. Plants Agric. Res., 7: 00264.

Rahman MH, MA Rahman, MMM Hossain, SM Yeasmin and AA Asif, 2015b. Effect of feeding management of broodstock on breeding performance of bata Labeo bata. Asian J. Med. Biol. Res., 1:553-568.

Rahman MM and MBR Chowdhury, 1999. Incidence of ulcer disease in African catfish (Clarias gariepnus) and trial its chemotherapy. BangladeshJournal of Fisheries Research, 3: 193-200.

Rahman MM, GU Ahmed and MT Hasan, 2015a. Seasonal variation of water quality parameters, clinical and histological observation of some small endangered open water fishes from Mymensingh and Sylhet region. Asian J. Med. Biol. Res., 1: 95-102.

Roberts RJ, 1993. Motile aeromonadsepticaemia. In: V Inglis, RJ Roberts and NR Bromage (Editors), Bacterial Diseases of Fish, Blackwell Scientific Publications, Oxford, United Kingdom. pp. 143-155.

Samuelson OB, 1989. Degradation of oxytetracycline in seawater at two different temperatures and light intensities and the persistence of oxytetracycline in the sediment from a fish farm.Aquaculture, 83: 7-16.

Scott WW and CO Warren, 1964. Studies of the host range and chemical control of fungi associated with diseased tropical fish. Bulletin Agricultural Experiment Station, 171: 1-24.

Shabuj MAI, T Bairagi, AA Asif, O Faruq, MR Bari and MS Neowajh, 2015. Shrimp disease investigation and culture strategies in Bagerhat district, Bangladesh. Asian J. Med. Biol. Res., 1: 545-552.

Sharmin S, MA Salam, F Haque, MS Islam and M Shahjahan, 2016. Changes in hematological parameters and gill morphology in common carp exposed to sub-lethal concentrations of Malathion. Asian J. Med. Biol. Res.,2: 370-378.

Subasinghe RP, U Barg and ATacon, 1996. Chemicals in Asian aquaculture: need, usage, issues and challenges. In: JR Arthur, CR Lavilla-Pitogo and RP Subasinghe (Editors), Use of Chemicals in Aquaculture in Asia. Southeast Asian Fisheries Development Center, Aquaculture Department Tigbauan, Iloilo, Philippines. pp. $1-6$.

Yeasmin SM, MA Rahman, MMM Hossain, MH Rahman and AA Asif, 2015. Identification of causative agent for fungal infection and effect of disinfectants on hatching and survival rate of common carp C. carpio larvae. Asian J. Med. Biol. Res., 1: 578-588.

Zahura UA, 2001. Fungal infection in freshwater fishes in Mymensingh area. MS Thesis, Department of Aquacuhture, Bangladesh Agricultural University, Mymensingh, Bangladesh. 